OPEN ACCESS

Edited by:

Yusuke Saijo,

Nara Institute of Science and

Technology (NAIST), Japan

Reviewed by:

Hiromu Kameoka,

Osaka Prefecture University, Japan Yang Bai,

Max Planck Institute for Plant Breeding

Research, Germany

${ }^{*}$ Correspondence:

Allen Yi-Lun Tsai

yi-lun.tsai@riken.jp

${ }^{\dagger}$ Present address:

Allen Yi-Lun Tsai,

Dormancy and Adaptation Research

Unit, RIKEN Center for Sustainable

Resource Science, Yokohama, Japan

FThese authors have contributed equally to this work

Specialty section:

This article was submitted to Plant Pathogen Interactions, a section of the journal

Frontiers in Plant Science

Received: 04 March 2020

Accepted: 20 July 2020

Published: 31 July 2020

Citation:

Tsai AY-L, Oota M and Sawa S (2020)

Chemotactic Host-Finding Strategies

of Plant Endoparasites

and Endophytes.

Front. Plant Sci. 11:1167.

doi: 10.3389/fpls.2020.01167

\section{Chemotactic Host-Finding Strategies of Plant Endoparasites and Endophytes}

\author{
Allen Yi-Lun Tsai ${ }^{\star \star \neq}$, Morihiro Oota ${ }^{\ddagger}$ and Shinichiro Sawa \\ Graduate School of Science and Technology, Kumamoto University, Kumamoto, Japan
}

Plants interact with microorganisms in the environment during all stages of their development and in most of their organs. These interactions can be either beneficial or detrimental for the plant and may be transient or long-term. In extreme cases, microorganisms become endoparastic or endophytic and permanently reside within a plant, while the host plant undergoes developmental reprogramming and produces new tissues or organs as a response to the invasion. Events at the cellular and molecular level following infection have been extensively described, however the mechanisms of how these microorganisms locate their plant hosts via chemotaxis remain largely unknown. In this review, we summarize recent findings concerning the signalling molecules that regulate chemotaxis of endoparasitic/endophytic bacteria, fungi, and nematodes. In particular, we will focus on the molecules secreted by plants that are most likely to act as guidance cues for microorganisms. These compounds are found in a wide range of plant species and show a variety of secondary effects. Interestingly, these compounds show different attraction potencies depending on the species of the invading organism, suggesting that cues perceived in the soil may be more complex than anticipated. However, what the cognate receptors are for these attractants, as well as the mechanism of how these attractants influence these organisms, remain important outstanding questions. Host-targeting marks the first step of plant-microorganism interactions, therefore understanding the signalling molecules involved in this step plays a key role in understanding these interactions as a whole.

Keywords: chemotaxis, endophytes, endoparasites, gall-forming bacteria, arbuscular mycorrhizal fungi, plant pathogenic nematode

\section{INTRODUCTION}

Plants do not live in solitary isolation but instead are constantly interacting with other organisms in their environment. Organisms known to interact with plants include herbivores, commensals, symbionts, and pathogens from multiple kingdoms. These organisms can interact with essentially any plant organ throughout all stages of plant development. Certain plant parasites and symbionts infect host-plant tissues and spend the majority of their lives within their host (Compant et al., 2010; Hassani et al., 2018). Such manipulation of host development has evolved independently several 
times and can be found in multiple classes of organisms, including bacteria, fungi, nematodes, mites, and insects (Barash and Manulis-Sasson, 2009; Dodueva et al., 2020).

Plant endoparasite/endophyte-induced structures can have profound effects in agriculture. Colonization by symbionts usually grants certain advantages to the host plant, such as enhanced nutrient acquisition, and is thus generally preferred (if not required) in agriculture (Khare et al., 2018). On the other hand, parasite-induced ectopic structures are typically signs of disease that reduce crop performance, and can sometimes be fatal. However, what remains unclear is how these organisms locate their hosts. Despite plants being sessile, endoparasites and endophytes nevertheless need to make an effort to locate their host plants. Some endoparasites and endophytes have very specific host ranges, while for others plant hosts are obligatory to complete their life cycles. As such, host-seeking is clearly a vital behavior in plant endoparasites and endophytes and one that requires intricate regulation. It is generally accepted that to locate host plants, endosymbionts and endoparasites sense attractants secreted by these plants. However, the mechanisms by which these attractants are perceived and identified generally remain unclear.

This review aims to explore the current status the chemotactic behaviors of plant endoparasite/endophyte, particularly those that induce host-plant structural remodeling. The chemotactic behavior and chemosensory mechanisms of bacteria, fungi, and nematodes toward plants will be introduced, summarizing chemotactic signaling systems established in these respective taxa using model organisms. The chemotactic mechanisms and known attractants for plant-infecting members of each taxon will then be discussed.

\section{ENDOPARASITIC AND ENDOPHYTIC BACTERIA}

The best-characterized examples of plant-infecting organisminduced plant developmental remodeling are caused by bacteria. Rhizobium radiobacter, the causative agent of crown gall disease, stimulates tumor formation on the shoots and roots of many plant species, while various rhizobia species colonize plant roots and form nodules to provide organic nitrogen in exchange for carbohydrates (Escobar and Dandekar, 2003; Poole et al., 2018). Multiple species of bacteria have been shown to migrate toward root exudates, and the rhizosphere is indeed known to be colonized by many species of microorganisms (Walker et al., 2003; Berendsen et al., 2012). However, the specific components within root exudates that soil bacteria respond to largely remain to be deciphered. In addition, exudate compositions also vary among root regions, adding temporal and spatial variations to bacterial behavior in the rhizosphere (Scharf et al., 2016). Lastly, root exudates can mediate bacterial colonization not only through chemotaxis but also through other means, such as promoting nodulation or inducing flagellin expression (Kierul et al., 2015; Li et al., 2016).

Chemotaxis has been well-characterized in the model organism Escherichia coli. The perception of chemotactic signals in $E$. coli is mediated by the core complex, which consists of four methyl-accepting chemotaxis proteins (MCPs) that act as chemoreceptors, and redox receptor Aer, histidine kinase CheA and adaptor protein CheW (Yang and Briegel, 2020). The core complexes in turn form large hexagonal clusters on the plasma membrane, known as the chemosensory array, and are responsible for phosphorylating downstream signalling modules upon chemoattractant binding (Yang and Briegel, 2020). Downstream targets of the core complex include CheB, which mediates sensory adaptation and inhibits the MCPs as a negative feedback signal, and $\mathrm{CheY}$, which controls flagellamediated locomotion (Wadhams and Armitage, 2004). By favoring long-flagella-mediated propulsion in the presence of chemoattractants, the bacterial cell gradually moves closer to the attractant.

The number of chemoreceptors and the tertiary structures of the core complex show great diversity among bacterial taxa, although in general the chemotactic machinery seen in E. coli is well-conserved among bacteria and serves as a suitable model system (Table 1). Currently, 19 bacterial chemotaxis systems have been identified; 17 based on the E. coli Che system, with two other unique systems known as type IV pili motility (Tfp) and alternative cellular function (ACF) (Wuichet and Zhulin, 2010). More than half of the motile bacteria possess multiple chemosensory systems, highlighting the importance of processing and fine-tuning chemosensory signalling and responses (Wuichet and Zhulin, 2010). Expectedly, the number and diversity of MCPs expressed in a given taxon correlate with its lifestyle and metabolism complexity (Lacal et al., 2010). Several species of soil bacteria have been documented to be attracted by organic acids, for which the cognate chemoreceptors have been identified in many species (Sampedro et al., 2015; Table 2). Other common bacterial chemoattractants include sugars and sugar alcohols (Bowra and Dilworth, 1981; Burg et al., 1982; Alexandre et al., 2000; Meier et al., 2007; Miller et al., 2007; Table 2).

Rhizobium radiobacter (formerly known as Agrobactetrium tumefaciens), the causative agent of crown gall disease, is perhaps the best-known endoparasitic organism that manipulates plant development. $R$. radiobacter probably targets molecules specifically released by wounding, since it infiltrates plant tissues via wound sites. As such, $R$. radiobacter has been shown to be attracted to various sugars, amino acids, opines, and phenolics (Ashby et al., 1987; Ashby et al., 1988; Loake et al., 1988; Kim and Farrand, 1998). One of the chemoreceptors, ChvE, has been shown to be essential for host-finding and shares structural homology with $E$. coli proteins known to bind galactose and glucose, suggesting ChvE may similarly function as a chemoreceptor for sugars (Cangelosi et al., 1990). Interestingly, $R$. radiobacter expresses two CheW homologues, both of which are required for chemotaxis towards plant tissue, yet neither is encoded in the Che operon (Huang et al., 2018).

Rhizobium leguminosarum is one of the best characterized rhizobia and is related to $R$. radiobacter; they both belong to the Rhizobiaceae family. $R$. leguminosarum forms nodules in the roots of legumes, such as peas, clovers, and various beans, and is 
TABLE 1 | Chemotactic genes of endoparasites and endophytes discussed in this review.

\begin{tabular}{|c|c|c|c|c|}
\hline $\begin{array}{l}\text { Endoparasite, } \\
\text { endophyte }\end{array}$ & Chemotactic gene & $\begin{array}{l}\text { Model organism } \\
\text { orthologues }\end{array}$ & Predicted functions & Reference \\
\hline \multirow{2}{*}{$\begin{array}{l}\text { Rhizobium } \\
\text { radiobacter } \\
\text { (bacteria) }\end{array}$} & ChvE & $\begin{array}{l}\text { E. coli galactose/glucose- } \\
\text { binding protein (GBP) }\end{array}$ & Putative sugar chemoreceptor & Cangelosi et al., 1990 \\
\hline & $\mathrm{CheW}_{1}, \mathrm{CheW}_{2}$ & E. coli CheW & $\begin{array}{l}\text { Scaffold protein binding chemoreceptor and } \\
\text { histidine kinase CheA }\end{array}$ & Huang et al., 2018 \\
\hline $\begin{array}{l}\text { Rhizobium } \\
\text { leguminosarum } \\
\text { (bacteria) }\end{array}$ & McpB, McpC & E. coli MCPs & Chemoreceptors with unknown ligands & Yost et al., 1998 \\
\hline \multirow[t]{5}{*}{$\begin{array}{l}\text { Sinorhizobium } \\
\text { meliloti } \\
\text { (bacteria) }\end{array}$} & $\begin{array}{l}\text { McpE, McpS, McpT, McpU, } \\
\text { McpV, McpW, McpX, McpY, } \\
\text { McpZ }\end{array}$ & E. coli MCPs & $\begin{array}{l}\text { Chemoreceptors for sugars, amino acids and } \\
\text { organic acids }\end{array}$ & Meier et al., 2007 \\
\hline & CheY1, CheY2 & E. coli CheY & $\begin{array}{l}\text { Binds and changes the rotation direction of } \\
\text { flagellar motor, }\end{array}$ & $\begin{array}{l}\text { Sourjik and Schmitt, 1996; } \\
\text { Sourjik and Schmitt, } 1998\end{array}$ \\
\hline & CheD & E. coli CheD & $\begin{array}{l}\text { Deaminase that regulates chemoreceptor } \\
\text { activities }\end{array}$ & Scharf et al., 2016 \\
\hline & Ches & N/A & Regulates phosphorylation of CheY1 & Dogra et al., 2012 \\
\hline & CheT & N/A & Required for chemotaxis, function unknown & Scharf et al., 2016 \\
\hline Fusarium & STE2 & S. cerevisiae Ste2 & Chemoreceptor for unknown host signal & Turrà et al., 2015 \\
\hline $\begin{array}{l}\text { oxysporum } \\
\text { (fungi) }\end{array}$ & Fmk1 & S. cerevisiae Fus3 and Kss1 & MAP kinase for chemotropism signaling, & Di Pietro et al., 2001 \\
\hline \multirow{3}{*}{$\begin{array}{l}\text { Meloidogyne } \\
\text { incognita } \\
\text { (nematode) }\end{array}$} & Mi-odr-1 & C. elegans odr-1 & $\begin{array}{l}\text { Membrane-bound guanylyl cyclase that produces } \\
\text { cGMP secondary messenger }\end{array}$ & Shivakumara et al., 2019 \\
\hline & Mi-odr-3 & C. elegans odr-3 & $\begin{array}{l}\text { G } \alpha \text { protein that regulates cyclic nucleotide } \\
\text { metabolism }\end{array}$ & Shivakumara et al., 2019 \\
\hline & Mi-tax-2, Mi-tax-4 & C. elegans tax-2 and tax-4 & $\begin{array}{l}\text { Subunits of cyclic nucleotide-gated cation } \\
\text { channel involved in G-protein-mediated signalling }\end{array}$ & Shivakumara et al., 2019 \\
\hline
\end{tabular}

an important contributor to nitrogen fixation. Its genome contains two chemotaxis operons, where Che1 is likely to be the main driver mediating chemotaxis toward sugars and is essential for host-finding and nodulation (Miller et al., 2007). $R$. leguminosarum has been shown to be attracted to amino acids and flavonoids (Armitage et al., 1988). In addition, two of its chemoreceptors, $\mathrm{McpB}$ and $\mathrm{McpC}$, are known to positively regulate nodulation, but their ligands remain unknown (Yost et al., 1998). The importance of these two receptors may be more relevant depending on the host species and competing soil microbiota (Yost et al., 1998).

Sinorhizobium meliloti is another well-characterized member of the Rhizobiaceae family. S. meliloti has been shown to colonize specific regions of alfalfa roots, confirming their preference for cues from specific parts of the roots (Gulash et al., 1984). The $S$. meliloti genome contains nine chemoreceptors, all of which were shown to be required for chemotaxis toward sugars, amino acids, and organic acids (Meier et al., 2007). Two CheY homologues are also present, with CheY2 controlling the unidirectional flagella motor speed, while CheY1 terminates the chemotaxis signal (Sourjik and Schmitt, 1996; Platzer et al., 1997; Sourjik and Schmitt, 1998; Attmannspacher et al., 2005). The chemotactic machineries are encoded in two operons (Meier et al., 2007; Meier and Scharf, 2009). The Che1 operon of S. meliloti contains the CheD deamidase that modulates chemoreceptor activities (Scharf et al., 2016). S. meliloti also expresses CheS, a novel protein that complexes with CheA to facilitate dephosphorylation of CheY1 (Dogra et al., 2012). CheT is another novel protein in S. meliloti Che1 operon required for chemotaxis, though its function is currently unknown (Scharf et al., 2016). S. meliloti has been documented to be attracted to luteolin, 4',7-dihydroxyflavone, 4',7-dihydroxyflavanone, and 4,4'-dihydroxy-2-methoxychalcone, all of which are found in root exudates (Caetano-Anollés et al., 1988; Dharmatilake and Bauer, 1992). In addition, S. meliloti has been shown to be attracted to amino acids in alfalfa seed exudates, which is mediated by McpU, as well as to common sugars (Götz et al., 1982; Malek, 1989; Meier et al., 2007; Webb et al., 2014; Webb et al., 2017a). Other known S. meliloti attractants include quaternary ammonium compounds (betonicine, choline, glycine betaine, stachydrine, and trigonelline), which are recognized by McpX (Webb et al., 2017b).

\section{ENDOPARASITIC AND ENDOPHYTIC FUNGI}

The other prominent class of organisms known to invade plant tissues is the fungi. Unlike bacteria, fungi are immobile and under most circumstances are not chemotactic. Nevertheless, plantsymbiotic and parasitic fungi make deliberate efforts to mediate hyphae growth toward potential hosts via chemotropism. Hyphae chemotropism towards plants was first described in Uromyces appendiculatus growing towards soybean leaf stomata, with the tips of hyphae recognized as the area responsible for sensing chemical cues and processing chemotropism (Turrà and Di Pietro, 2015; Turrà et al., 2016). By 1905, it was noted that the constituents of host exudates dictated the type of fungi attracted, which consolidates the importance of chemotaxis in plant parasitism (Massee, 1905). 
TABLE 2 | Chemoattractants of endoparasites and endophytes discussed in this review.

\begin{tabular}{|c|c|c|c|c|}
\hline $\begin{array}{l}\text { Attractant } \\
\text { class }\end{array}$ & Perceived by & Attractants & Notes & References \\
\hline \multirow[t]{5}{*}{$\begin{array}{l}\text { Sugars and } \\
\text { alcohols }\end{array}$} & $\begin{array}{l}\text { Rhizobium radiobacter } \\
\text { (bacteria) }\end{array}$ & $\begin{array}{l}\text { Sucrose, glucose, fructose, maltose, } \\
\text { lactulose, galactose, raffinose, } \\
\text { stachyose, arabinose }\end{array}$ & May be perceived by chemoreceptor ChvE & $\begin{array}{l}\text { Loake et al., 1988; Cangelosi } \\
\text { et al., } 1990\end{array}$ \\
\hline & $\begin{array}{l}\text { Rhizobium leguminosarum } \\
\text { (bacteria) }\end{array}$ & Mannitol, galactose & $\begin{array}{l}\text { Perception requires the Che1 chemotaxis } \\
\text { operon }\end{array}$ & Miller et al., 2007 \\
\hline & $\begin{array}{l}\text { Sinorhizobium meliloti } \\
\text { (bacteria) }\end{array}$ & $\begin{array}{l}\text { Fructose, galactose, maltose, } \\
\text { mannitol, sucrose }\end{array}$ & $\begin{array}{l}\text { Perception requires all } 9 \text { chemoreceptors } \\
\text { McpE, McpS-McpZ }\end{array}$ & Meier et al., 2007 \\
\hline & & $\begin{array}{l}\text { Sucrose, glucose, arabinose, } \\
\text { galactose }\end{array}$ & & Malek, 1989 \\
\hline & $\begin{array}{l}\text { Meloidogyne incognita } \\
\text { (nematode) }\end{array}$ & Mannitol & $\begin{array}{l}\text { Signal transduction may require Mi-odr-1, } \\
\text { Mi-odr-3, Mi-tax- } 2 \text { and Mi-tax-4 }\end{array}$ & $\begin{array}{l}\text { Fleming et al., 2017; Shivakumara } \\
\text { et al., } 2019\end{array}$ \\
\hline \multirow[t]{3}{*}{$\begin{array}{l}\text { Organic } \\
\text { acids }\end{array}$} & $\begin{array}{l}\text { Rhizobium leguminosarum } \\
\text { (bacteria) }\end{array}$ & Pyruvate, succinate & $\begin{array}{l}\text { Perception requires the Che } 1 \text { chemotaxis } \\
\text { operon }\end{array}$ & Miller et al., 2007 \\
\hline & $\begin{array}{l}\text { Sinorhizobium meliloti } \\
\text { (bacteria) }\end{array}$ & Citrate, fumarate, malate, succinate & $\begin{array}{l}\text { Perception requires all } 9 \text { chemoreceptors } \\
\text { McpE, McpS-McpZ }\end{array}$ & Meier et al., 2007 \\
\hline & $\begin{array}{l}\text { Meloidogyne incognita } \\
\text { (nematode) }\end{array}$ & Vanillic acid, lauric acid & $\begin{array}{l}\text { Signal transduction may require Mi-odr-1, } \\
\text { Mi-odr-3, Mi-tax-2 and Mi-tax-4. }\end{array}$ & $\begin{array}{l}\text { Dong et al., 2014; Fleming et al., } \\
\text { 2017; Shivakumara et al., } 2019\end{array}$ \\
\hline \multirow[t]{6}{*}{$\begin{array}{l}\text { Amino } \\
\text { acids }\end{array}$} & $\begin{array}{l}\text { Rhizobium radiobacter } \\
\text { (bacteria) }\end{array}$ & Valine, arginine & & Loake et al., 1988 \\
\hline & $\begin{array}{l}\text { Rhizobium leguminosarum } \\
\text { (bacteria) }\end{array}$ & Homoserine & & Armitage et al., 1988 \\
\hline & $\begin{array}{l}\text { Sinorhizobium meliloti } \\
\text { (bacteria) }\end{array}$ & All standard amino acids & $\begin{array}{l}\text { Perception requires all } 9 \text { chemoreceptors } \\
\text { McpE, McpS-McpZ }\end{array}$ & $\begin{array}{l}\text { Götz et al., 1982; Malek, 1989; } \\
\text { Meier et al., 2007; Webb et al., } \\
\text { 2014; Webb et al., 2017a }\end{array}$ \\
\hline & & $\begin{array}{l}\text { Citrulline, } \gamma \text {-aminobutyric acid, } \\
\text { ornithine }\end{array}$ & Perception requires chemoreceptor $\mathrm{McpU}$ & Webb et al., 2017a \\
\hline & & Homoserine & & Götz et al., 1982 \\
\hline & $\begin{array}{l}\text { Meloidogyne incognita } \\
\text { (nematode) }\end{array}$ & Argenine, lysine & $\begin{array}{l}\text { Signal transduction may require Mi-odr-1, } \\
\text { Mi-odr-3, Mi-tax- } 2 \text { and Mi-tax-4 }\end{array}$ & $\begin{array}{l}\text { Fleming et al., 2017; Shivakumara } \\
\text { et al., } 2019\end{array}$ \\
\hline \multirow[t]{2}{*}{ Phenolics } & $\begin{array}{l}\text { Rhizobium radiobacter } \\
\text { (bacteria) }\end{array}$ & $\begin{array}{l}\text { Acetosyringone, sinapinic acid, } \\
\text { syringic acid }\end{array}$ & & $\begin{array}{l}\text { Ashby et al., 1987; Ashby et al., } \\
1988\end{array}$ \\
\hline & $\begin{array}{l}\text { Meloidogyne incognita } \\
\text { (nematode) }\end{array}$ & Tannic acid & $\begin{array}{l}\text { Signal transduction may require Mi-odr-1, } \\
\text { Mi-odr-3, Mi-tax-2 and Mi-tax-4 }\end{array}$ & $\begin{array}{l}\text { Fleming et al., 2017; Shivakumara } \\
\text { et al., } 2019\end{array}$ \\
\hline \multirow[t]{2}{*}{ Flavonoids } & $\begin{array}{l}\text { Rhizobium leguminosarum } \\
\text { (bacteria) }\end{array}$ & Apigenin, naringenin, kaempferol & & Armitage et al., 1988 \\
\hline & $\begin{array}{l}\text { Sinorhizobium meliloti } \\
\text { (bacteria) }\end{array}$ & $\begin{array}{l}\text { Luteolin, 4',7-dihydroxyflavone, 4',7- } \\
\text { dihydroxyflavanone, and 4,4'- } \\
\text { dihydroxy-2-methoxychalcone }\end{array}$ & & $\begin{array}{l}\text { Caetano-Anollés et al., 1988; } \\
\text { Dharmatilake and Bauer, } 1992\end{array}$ \\
\hline \multirow[t]{2}{*}{$\begin{array}{l}\text { Phyto- } \\
\text { hormones }\end{array}$} & $\begin{array}{l}\text { Gigaspora margarita } \\
\text { (fungi) }\end{array}$ & Strigolactone & $\begin{array}{l}\text { Likely perceived by novel receptors not } \\
\text { conserved in plants. }\end{array}$ & $\begin{array}{l}\text { Akiyama et al., 2005; Akiyama } \\
\text { and Hayashi, 2006; Gutjahr, } \\
\text { 2014; Boyer et al., } 2014\end{array}$ \\
\hline & $\begin{array}{l}\text { Meloidogyne incognita } \\
\text { (nematode) }\end{array}$ & $\begin{array}{l}\text { 6-Dimethylallylaminopurine, salicylic } \\
\text { acid, gibberellic acid, Indole-3-acetic } \\
\text { acid }\end{array}$ & $\begin{array}{l}\text { Signal transduction may require Mi-odr-1, } \\
\text { Mi-odr-3, Mi-tax-2 and Mi-tax-4 }\end{array}$ & $\begin{array}{l}\text { Fleming et al., 2017; Shivakumara } \\
\text { et al., } 2019\end{array}$ \\
\hline \multirow[t]{2}{*}{$\begin{array}{l}\text { Organic } \\
\text { amines }\end{array}$} & $\begin{array}{l}\text { Sinorhizobium meliloti } \\
\text { (bacteria) }\end{array}$ & $\begin{array}{l}\text { Betonicine, choline, glycine betaine, } \\
\text { stachydrine, trigonelline }\end{array}$ & Perception requires chemoreceptor McpX & Webb et al., 2017b \\
\hline & $\begin{array}{l}\text { Meloidogyne incognita } \\
\text { (nematode) }\end{array}$ & $\begin{array}{l}\text { Cadaverine, 1,3-diaminopropane, } \\
\text { putrescine }\end{array}$ & & Oota et al., 2019 \\
\hline Opines & $\begin{array}{l}\text { Rhizobium radiobacter } \\
\text { (bacteria) }\end{array}$ & $\begin{array}{l}\text { Octopine, nopaline, mannopine, } \\
\text { agrocinopines } A+B\end{array}$ & & Kim and Farrand, 1998 \\
\hline \multirow[t]{4}{*}{ Others } & $\begin{array}{l}\text { Rhizobium leguminosarum } \\
\text { (bacteria) }\end{array}$ & Unknown host signal & $\begin{array}{l}\text { Perception requires chemoreceptors } \mathrm{McpB} \\
\text { and } \mathrm{McpC}\end{array}$ & Yost et al., 1998 \\
\hline & $\begin{array}{l}\text { Fusarium oxysporum } \\
\text { (fungi) }\end{array}$ & Unknown host signal & $\begin{array}{l}\text { Perception requires } \alpha \text {-STE2 chemoreceptor } \\
\text { and Fmk1 MAPK kinase, signal requires } \\
\text { peroxidase activity from host }\end{array}$ & Turrà et al., 2015 \\
\hline & $\begin{array}{l}\text { Trichoderma harzianum } \\
\text { (fungi) }\end{array}$ & Unknown host signal & $\begin{array}{l}\text { requires stress, peroxidase and oxylipin } \\
\text { activities from host }\end{array}$ & Lombardi et al., 2018 \\
\hline & $\begin{array}{l}\text { Meloidogyne incognita } \\
\text { (nematode) }\end{array}$ & Calcium chloride & & Wang et al., 2018 \\
\hline
\end{tabular}


In a similar way to how $E$. coli serves as a model for bacterial chemotaxis, studies using Saccharomyces cerevisiae and Neurospora crassa have provided invaluable insights into fungal chemotropism (Table 1). S. cerevisiae cells develop mating projections known as shmoos in the presence of the opposite mating type, by detecting secreted mating peptide pheromone a or $\alpha$. These pheromones are perceived by seven transmembrane G-protein-coupled receptors; MATa cells express Ste2, which binds the $\alpha$ - pheromone, while MAT $\alpha$ cells express Ste3, which binds the a-pheromone (Hagen et al., 1986; Blumer et al., 1988). The receptors function as guanine exchange factors and activates the G $\alpha$ subunit (GPA1) upon pheromone-binding, which promotes the dissociation of the G $\beta \gamma$ subunits (STE4 and STE18) from the complex (Schrick et al., 1997). This then initiates a signalling cascade mediated by Fus3 and Kss1 (MAPK), leading to transcriptional regulation, cell cycle arrest, cell shape alternation, and ultimately shmoo development toward the mating partner (Arkowitz, 2009). In an analogous case, female hyphae of Neurospora crassa (trichogyne) grow towards male spores via chemotropism. This process is mediated by the spore pheromone peptides MFA-1 and CCG-4, which are perceived by the receptors PRE-1 and PRE-2 (orthologues of Ste2 and Ste3), respectively (Kim and Borkovich, 2004; Kim and Borkovich, 2006). Pheromone perception in $N$. crassa initiates a similar MAPK signalling cascade mediated by heterotrimeric G-proteins (Dettmann et al., 2014). Another case of chemotropism in N. crassa is anastomosis, where hyphae from cells of an identical genotype (sometimes the same cell) are attracted towards each other, followed by fusion (Leeder et al., 2011). The anastomosis chemotropism signal is similarly transduced by a MAPK cascade using orthologues of Fus3 and Kss1 (Read et al., 2009). The $N$. crassa anastomosis signal may be a peptide pheromone (Roca et al., 2005), and it has been hypothesized that both parties use the same signalling molecule, which positively regulates itself (Read et al., 2012). Lastly, hyphae repellants may also play a role in chemotropism, and the direction of hyphae growth is likely to be a balance between attraction and repulsion (Leeder et al., 2011).

Hyphal chemotropism in response to plants is wellcharacterized in pathogens of the genus Fusarium, which are ubiquitous, filamentous ascomycete fungi. Fusarium oxysporum spores respond to host cues in order to germinate, and its hyphae elongate toward host roots using chemotropism. Although $F$. oxysporum does not manipulate the host's developmental program, it nevertheless serves as a good model to decipher how yeast chemotropism has been specialized for pathogenesis. F. oxysporum requires the $\alpha$-STE2 signalling module and Fmk1 (an orthologue of Fus3 and Kss1) for infection (Di Pietro et al., 2001; Turrà et al., 2015). Considering F. oxysporum does not undergo sexual reproduction, the conserved mating pheromone chemotropism pathway may have evolved to detect host signals (Turrà et al., 2015). F. oxysporum has been shown to be able to distinguish between live and dead cells, suggesting it is likely to be able to perceive certain live cell-exclusive signals (van der Does et al., 2008). Furthermore, F. oxysporum root-targeting behavior has been shown to require the secretion of a haemcontaining peroxidase released from root wounds (Turrà et al., 2015), suggesting the product of this peroxidase may be a potential chemoattractant, in addition to nutrients such as amino acids and sugars. On the other hand, the biocontrol agent Trichoderma harzianum has been shown to be preferentially attracted to root exudate secreted by tomato plants under stress; peroxidase and oxylipins are required in the exudate for this attraction to occur (Lombardi et al., 2018). Interestingly, stress did not enhance the attraction of tomato root exudate to $F$. oxysporum, even though peroxidase has been shown to be an important element in F. oxysporum chemotropism (Turrà et al., 2015; Lombardi et al., 2018). The specific identities of the peroxidase-dependent attractants for $F$. oxysporum may be more complicated than expected.

The fungal counterparts of the bacterial rhizobia are the arbuscular mycorrhizal fungi (AMF). AMF include the Glomeromycetes, obligate symbionts that form highly branched structures known as arbuscules to mediate nutrient exchange with their host root's cortical cells. AMF provide their plant hosts with various nutrients, predominantly inorganic phosphate, while receiving photosynthetic products such as hexoses and fatty acids from their host (Jiang et al., 2017; Luginbuehl et al., 2017). AMF have been estimated to colonize $\sim 80 \%$ of all land plants, while fossil records suggest plant-AMF symbioses occurred as early as 460 million years ago, coinciding with the colonization of land by plants (Martin et al., 2017; Strullu-Derrien et al., 2018). These lines of evidence suggest AMF may be a key factor in plant terrestrial adaptation. AMF probably locate their host plants by recognizing molecules from root exudates, as root exudates have been shown to promote AMF spore germination and hyphal branching. The phytohormone strigolactone (SL) has been shown to promote hyphal branching in Gigaspora margarita (Akiyama et al., 2005; Akiyama and Hayashi, 2006; Table 2), while pea plants deficient in SL synthesis show reduced AMF colonization (Gómez-Roldán et al., 2008). Specifically, SL treatment stimulates AMF mitochondria proliferation and shape change, and increases metabolism (Besserer et al., 2006; Besserer et al., 2008; Besserer et al., 2009). SL also induces spore germination in AMF (Besserer et al., 2006; Besserer et al., 2008). Together, these lines of evidence confirm that secreted SL is indeed a vital positive regulator of AMF colonization. No fungal receptor of SL has yet been identified, but it is likely to be different from the plant SL receptor, since G. margarita perceives different forms of SL than plants do (Gutjahr, 2014; Boyer et al., 2014), and the Rhizophagus irregularis genome does not appear to contain orthologues of plant SL receptors (Tisserant et al., 2012).

On the other hand, SL is probably not the only molecule that AMF target for host-localization. Plants deficient in SL synthesis show a reduction in, but not the abolishment of, AMF colonization (Gómez-Roldán et al., 2008), while AMF non-host plants have also been shown secrete SL from their roots, albeit at lower levels (Goldwasser et al., 2008; Yoneyama et al., 2008). It seems plausible that SL-insensitive AMF can still colonize roots if encountered by chance, and SL merely functions to enhance 
host-guidance but is not essential for colonization. AMF species including Gigaspora gigantean and Glomus mosseae, and ectomycorrhizal fungal species including Pisolithus tinctorius and Paxillus involutus have been shown to prefer host roots over non-hosts or dead plants (Koske, 1982; Horan and Chilvers, 1990; Sbrana and Giovannetti, 2005). Since SL appears to be ubiquitously found in all plants, the presence of SL alone is not sufficient to dictate AMF colonization. Other root-derived AMF branching factors probably exist, but the situation is complicated since different compounds may have different effects on the same AMF, while the same compound may have different effects on different AMF (Nagahashi and Douds, 2000; Nagahashi and Douds, 2007). Different forms of SL may also have different attracting strengths and activities.

\section{ENDOPARASITIC NEMATODES}

Another class of endoparasitic plant pathogens known to cause novel organ formation and developmental reprogramming of the host is the nematodes. The major nematode plant pathogens comprise the root-knot nematodes (RKNs, genus Meloidogyne), the cyst nematodes ( $\mathrm{CN}$, genera Heterdera and Globodera) and the pine-wilt nematodes (PWN, Bursaphelenchus xylophilus). Although RKNs and CNs appear to have evolved independently, both use infection mechanisms that have much in common. In both cases, second-instar juveniles (J2) roam freely in the soil searching for the roots of appropriate host plants. Once a suitable root has been identified, the J2s infect the root and inject effectors that reprogram the host's vascular cells to form specialized feeding organs (Bartlem et al., 2014; Favery et al., 2016). RKNs stimulate host cells to undergo endoreduplication and form multi-nucleated giant cells, while CNs merge multiple host cells together to form syncytia (Siddique and Grundler, 2018). The nematodes then feed on these specialized organs and develop to maturity, whereupon females emerge from the roots to lay eggs and release the next generation to the environment.

$\mathrm{J} 2$ host-targeting behavior is therefore critical in plant parasitic nematode biology, and chemotaxis towards plant exudates has been associated with this behavior. Soybean, pea, potato, tomato, and rice root exudates have all been shown to attract J2s of various plant pathogenic nematodes (Papademetriou and Bone, 1983; Zhao et al., 2000; Reynolds et al., 2011; Xu et al., 2015; Yang et al., 2016; Čepulytè et al., 2018). Specifically, phenolics, flavonoids, glycoside, fatty acids, and diamines in exudates and volatiles from roots have been shown to act as nematode attractants (Chitwood, 2002; Zhao et al., 2007; Ohri and Pannu, 2010; Ali et al., 2011; Oota et al., 2019; Table 2). In addition, Arabidopsis seeds were also shown to attract $\mathrm{RKN}$, suggesting RKN may interact with plant seeds as well aside from roots (Tsai et al., 2019). Furthermore, it was revealed that nematode attractants and repellents are produced not only by plants but also by nematodes themselves. Many plant-parasitic nematodes have been shown to produce ascarosides, a class of glycolipidbased signaling molecules synthesized almost exclusively by nematodes (Manosalva et al., 2015). Depending on the types and compositions, ascarosides can regulate the aggregation/ dispersion of conspecifics or even other nematodes (Manohar et al., 2020). On the other hand, other compounds have also been documented to influence nematode behavior such as carbon dioxide; the amino acids arginine and lysine; phenolic acids; the plant hormones salicylic acid and gibberellic acid; the growth supplement ethephon; 6-dimethylallylaminopurine; and nitrate analogues (Pline and Dusenbery, 1987; Wang et al., 2009; Wang et al., 2010; Fleming et al., 2017; Hosoi et al., 2017; Table 2).

Caenorhabditis elegans has been established as a model organism for nematodes, and its genome, cell development pathway and nervous system have been extensively characterized. By examining elements conserved among C. elegans and plant pathogenic nematodes it may be possible to further expand our knowledge of pathogenic nematode behavior. Chemotaxis in nematodes is regulated by the amphid and phasmid sensory organs in their head and tail, respectively. In C. elegans, a pair of amphids acts as the main sensory organs, which contain twelve types of sensory neurons. By using laser ablation of individual or combinations of neurons, the corresponding stimulant signals being transmitted by each neuron can be identified (Mori, 1999; Rengarajan and Hallem, 2016). Despite the fact that the neural structures of plant-parasitic nematodes are at least somewhat conserved with C.elegans, molecular evidence suggests plant-parasitic nematodes likely evolved from fungivorous ancestors, which are likely evolutionarily distant from bacterivorous C. elegans (Quist et al., 2015). Cautions should be applied when inferring homology relationships between plant-parasitic nematodes and $C$. elegans to account for their evolutionary divergence and different foraging preferences.

Olfactory receptors are highly expressed in the sensory neurons and play important roles in sensing specific signals. For example, the AWA neuron expresses the ODR-10 receptor, which is responsible for diacetyl detection, and consequently odr-10 mutants fail to detect diacetyl compounds (Sengupta et al., 1996). Currently, 194 putative olfactory receptor genes have been identified in the C. elegans genome (Taniguchi et al., 2014). Therefore, we performed homology searches to look for orthologues of $C$. elegans olfactory receptors in the genomes of plant pathogenic nematodes, including the RKNs Meloidogyne incognita and Meloidogyne arenaria, the CNs Heterodera glycines and Globodera rostochiensis, and the PWN B. xylophilus (Table 3). Interestingly, the majority of $C$. elegans olfactory receptors are not conserved among plant pathogenic nematodes, although the few receptor orthologues that are present may be informative in determining their chemotactic behaviors. The B. xylophilus genome contains orthologues of SRV-11 (pentanedione avoidance), SRV-12 (benzaldehyde attraction), SRSX-26 (butanone attraction), SRSX-32 (pyrazine attraction), SRSX-33 (pentanedione and pyrazine attraction), SRSX-37 (pentanedione attraction), SRT-18 and SRT-25 (diacethyl avoidance). Meanwhile, the $M$. incognita and $M$. arenaria genomes contain orthologues of SRG-37 (pyrazine attraction). It would be interesting to determine whether the functions of these receptors are conserved among pathogenic nematodes and similarly regulate 
TABLE 3 | C. elegans olfactory receptor orthologues present in plant pathogenic nematodes, their predicted functions, and E-values of DNA sequence similarities.

\begin{tabular}{|c|c|c|c|c|}
\hline C. elegans GPCR & Predicted function & Species & Orthologue & E-value \\
\hline \multirow[t]{3}{*}{ SRV-11 } & Pentanedione avoidance & B. xylophilus & BXY_0066100 & $3.00 \mathrm{E}-11$ \\
\hline & & B. xylophilus & BXY_1231200 & $4.00 E-10$ \\
\hline & & B. xylophilus & BXY_0069300 & 2.00E-09 \\
\hline \multirow[t]{3}{*}{ SRV-12 } & Benzaldehyde attraction & B. xylophilus & BXY_0066100 & $5.00 \mathrm{E}-10$ \\
\hline & & B. xylophilus & BXY_1231200 & 3.00E-07 \\
\hline & & B. xylophilus & BXY_0069300 & 1.00E-06 \\
\hline \multirow[t]{2}{*}{ SRSX-26 } & Butanone attraction & B. xylophilus & BXY_1070000 & $4.00 \mathrm{E}-10$ \\
\hline & & B. xylophilus & BXY_1013200 & 1.00E-07 \\
\hline \multirow[t]{5}{*}{ SRSX-32 } & Pyrazine attraction & B. xylophilus & BXY_1070000 & $3.00 \mathrm{E}-10$ \\
\hline & & B. xylophilus & BXY_1013200 & 2.00E-07 \\
\hline & & B. xylophilus & BXY_1013400 & 4.00E-05 \\
\hline & & B. xylophilus & BXY_0557500 & 6.00E-04 \\
\hline & & B. xylophilus & BXY_0027800 & 9.00E-04 \\
\hline \multirow[t]{5}{*}{ SRSX-33 } & Pentanedione and pyrazine attraction & B. xylophilus & BXY_1070000 & 2.00E-06 \\
\hline & & B. xylophilus & BXY_0809300 & 3.00E-06 \\
\hline & & B. xylophilus & BXY_1013400 & 3.00E-05 \\
\hline & & B. xylophilus & BXY_0557500 & 9.00E-05 \\
\hline & & B. xylophilus & BXY_0027800 & 2.00E-04 \\
\hline SRSX-37 & Pentanedione attraction & B. xylophilus & BXY_1013400 & 3.00E-09 \\
\hline SRT-18 & Diacethyl avoidance & B. xylophilus & $\mathrm{BXY}_{-} 1024600$ & 5.00E-20 \\
\hline SRT-25 & Diacethyl avoidance & B. xylophilus & BXY_1024600 & 9.00E-20 \\
\hline \multirow[t]{2}{*}{ SRG-37 } & Pyrazine attraction & M. incognita & Minc3s00775g17185 & 2.30E-02 \\
\hline & & M. arenaria & tig00002579.g60974 & 5.90E-02 \\
\hline
\end{tabular}

Homologies were determined using Protein BLAST from WormBase ParaSite (https://parasite.wormbase.org/index.html) with the protein sequences of the 194 C. elegans

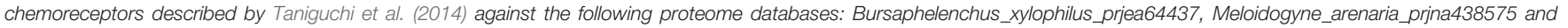
Meloidogyne_incognita_prjeb8714, Globodera_rostochiensis_prjeb13504, and Heterodera_glycines_prjna381081 using the default setting.

chemotaxis. On the other hand, H. glycines and G. rostochiensis genomes contain no orthologues of C. elegans olfactory receptors. This surprisingly low level of conservation of olfactory receptors suggests plant pathogenic nematodes have independently evolved unique signalling pathways to detect chemical signals. Meanwhile, four C. elegans chemosensory gene orthologues were identified in M. incognita as Mi-odr-1, Mi-odr-3, Mi-tax-2 and Mi-tax-4, where knockdown mutants showed defects in their attraction to root exudates, volatile compounds (alcohols, ketones, aromatic compounds, esters, thiazole, and pyrazine), non-volatile compounds (carbohydrates, phytohormones, organic acids, amino acids, and phenolics), as well as ascaroside signalling (Shivakumara et al., 2019; Table 1). These putative M. incognita-specific chemosensory signaling modules are likely to play important roles in host-targeting, and the identification of the corresponding olfactory receptors for these pathways may help identify specific RKN chemoattractants.

\section{OUTSTANDING CHALLENGES AND FUTURE PERSPECTIVES}

Aside from microorganisms, many arthropod species are also known to be endoparasitic and can manipulate their host plant's developmental program during infection. Insects from the orders Hemiptera and Hymenoptera and mites from the superfamily Eriophyoidea include endoparasitic members that form galls. Similar to the ectopic organs formed by endoparasitic/ endophytic microbes, galls induced by endoparasitic arthropods function as feeding organs and/or physical barriers for protection.
Mechanisms that mediate arthropod-mediated galling through phytohormone manipulation have been characterized in great detail (Tooker and Helms, 2014; de Lillo et al., 2018). However, how arthropod parasites locate their host plants has been relatively poorly investigated, for various reasons. First, arthropods may not rely heavily on chemotaxis to find hosts. Endoparasitic arthropods typically have poor mobility and rely on random forces for locomotion, such as wind (Nault and Styer, 1969; Sabelis and Bruin, 1996). Other endoparasitic arthropods specialize in infecting a single long-lived host plant, where progenies can continue to infect the same host as their parents (Lindquist and Oldfield, 1996; Manson and Oldfield, 1996). Second, arthropodinduced galls are among the most structurally diverse, with 13,000 insect species documented to form plant galls. Galling behavior appears to have evolved in arthropods multiple times, possibly through horizontal gene transfer from symbiotic bacteria or fungi (Gullan et al., 2005; Raman et al., 2005). Therefore, no single model organism system may be sufficient to represent the molecular signalling mechanisms for chemotaxis in endoparasitic arthropods, and these behaviors may have to be addressed in a caseby-case fashion.

Another major challenge in the characterization of plant endoparasites and endophytes are tri-trophic and other interactions that involve more parties. In nature, it is likely that plants will simultaneously encounter several of the endoparasites and endophytes discussed above, considering the same chemicals may attract organisms from multiple taxons. The outcome of these complex interactions will not be easy to predict under controlled laboratory conditions. For example, Fusarium solani, a plant fungal pathogen related to F. oxysporum, has been shown to induce virulence genes in response to the 
isoflavanoid pisatin in host roots, which is made by plants during stress (Straney et al., 1994; Straney et al., 2002). Similarly, the plant pathogenic nematode $M$. incognita can be attracted to polyamines from plant root exudates, which are also known to be produced in stressed plants (Oota et al., 2019). It appears that pathogens from multiple taxa tend to favor stressed plants, making simultaneous infection or colonization very likely scenarios in nature. On the other hand, SL has been shown to not only promote hyphal branching in AMF but also the germination of parasitic plants of the genera Striga and Orobanche (Cook et al., 1966; Cardoso et al., 2011). The plant SL production levels fluctuate during the course of AMF infection, with SL-synthesis genes up-regulated during early infection, and down-regulated during later infection stages (LópezRáez et al., 2015; Kobae et al., 2018). Furthermore, host plants utilize overlapping signalling components in response to both AMF and rhizobia infections, suggesting the two processes may have evolved together (Hirsch and Kapulnik, 1998; Guinel and Geil, 2002; Vierheilig and Piché, 2002; Parniske, 2008). Plants inoculated with rhizobia also show reduced Orobanche infection (Mabrouk et al., 2007a; Mabrouk et al., 2007b; Mabrouk et al., 2007c), while SL-synthesis genes are up-regulated during rhizobia colonization (Breakspear et al., 2014; van Zeijl et al., 2015). These lines of evidence suggest the interactions between host plants, rhizobia, $\mathrm{AMF}$, and parasitic plants mediated by SL require more elaborate analysis to decipher.

In general, it appears that most known attractants of plant endoparasites and endophytes consist of common compounds such as metabolites and plant hormones, instead of unique or unusual compounds. Currently it remains very difficult to use chemotactic behavior alone to explain endoparasites'endophytes' host range. The more likely explanation may be that soil microorganisms sense and respond to multiple chemoattractant simultaneously. Plants may also produce chemoattractants that are toxic to attracted microorganisms. Lauric acid has been shown to have different effects on $M$. incognita depending on concentrations (Dong et al., 2014). Abiotic environmental factors may also influence the behavior of soil microorganisms. Factors such as $\mathrm{pH}$, ions and temperature, redox potential,

\section{REFERENCES}

Akiyama, K., and Hayashi, H. (2006). Strigolactones: chemical signals for fungal symbionts and parasitic weeds in plant roots. Ann. Bot. 97, 925-931. doi: 10.1093/aob/mcl063

Akiyama, K., Matsuzaki, K., and Hayashi, H. (2005). Plant sesquiterpenes induce hyphal branching in arbuscular mycorrhizal fungi. Nature 435, 824-827. doi: 10.1038 /nature 03608

Alexandre, G., Greer, S. E., and Zhulin, I. B. (2000). Energy taxis is the dominant behavior in Azospirillum brasilense. J. Bacteriol. 182, 6042-6048. doi: 10.1128/ JB.182.21.6042-6048.2000

Ali, J. G., Alborn, H. T., and Stelinski, L. L. (2011). Constitutive and induced subterranean plant volatiles attract both entomopathogenic and plant parasitic nematodes. J. Ecol. 99 (1), 26-35. doi: 10.1111/j.1365-2745.2010.01758.x

Arkowitz, R. A. (2009). Chemical gradients and chemotropism in yeast. Cold Spring Harb. Perspect. Biol. 1, a001958. doi: 10.1101/cshperspect.a001958

Armitage, J. P., Gallagher, A., and Johnston, A. W. (1988). Comparison of the chemotactic behaviour of Rhizobium leguminosarum with and without the chelating compounds, and electrical potential have been documented to affect the behavior of plant parasitic nematodes (Rasmann et al., 2012). Therefore, endoparasite/endophyte host-targeting behavior is likely to be complex, involving both biotic and abiotic factors. Nevertheless, the identification and characterization of chemoattractants can have practical applications in agriculture. These chemoattractants or repellants may be applied in fields directly to manipulate the microorganisms behaviors, and ultimately improve the growth of crop plants. The chemotactic behaviors of different organisms may even be combined, as $C$. elegans has been shown to be capable of carrying rhizobia bacteria to plant hosts through phoresis (Horiuchi et al., 2005). With the identification of more chemoattractants, more sophisticated agricultural application strategies may eventually be designed and implemented in the future.

\section{DATA AVAILABILITY STATEMENT}

The datasets presented in this study can be found in online repositories. The names of the repository/repositories and accession number(s) can be found in the article/ supplementary material.

\section{AUTHOR CONTRIBUTIONS}

AY-LT and SS conceptualized the work. AY-LT, MO, and SS wrote the article.

\section{FUNDING}

This work was supported by JSPS KAKENHI (Grant Numbers 16F16406, 16K14757, 17H03967, 18H05487, and 20H00422) awarded to SS. nodulation plasmid. Mol. Microbiol. 2 (6), 743-748. doi: 10.1111/j.13652958.1988.tb00085.x

Ashby, A. M., Watson, M. D., and Shaw, C. H. (1987). A Ti-plasmid determined function is responsible for chemotaxis of Agrobacterium tumefaciens towards the plant wound product acetosyringone. FEMS Microbiol. Lett. 41, 189-192. doi: 10.1111/j.1574-6968.1987.tb02194.x

Ashby, A. M., Watson, M. D., Loake, G. J., and Shaw, C. H. (1988). Ti plasmidspecified chemotaxis of Agrobacterium tumefaciens C58C1 toward virinducing phenolic compounds and soluble factors from monocotyledonous and dicotyledonous plants. J. Bacteriol. 170, 4181-4187. doi: 10.1128/ JB.170.9.4181-4187.1988

Attmannspacher, U., Scharf, B., and Schmitt, R. (2005). Control of speed modulation (chemokinesis) in the unidirectional rotary motor of Sinorhizobium meliloti. Mol. Microbiol. 56, 708-718. doi: 10.1111/j.13652958.2005.04565.x

Barash, I., and Manulis-Sasson, S. (2009). Recent evolution of bacterial pathogens: the gall-forming Pantoea agglomerans case. Annu. Rev. Phytopathol. 47, 133 152. doi: 10.1146/annurev-phyto-080508-081803 
Bartlem, D. G., Jones, M. G. K., and Hammes, H. Z. (2014). Vascularization and nutrient delivery at root-knot nematode feeding sites in host roots. J. Exp. Bot. 65, 1789-1798. doi: 10.1093/jxb/ert415

Berendsen, R. L., Pieterse, C. M., and Bakker, P. A. (2012). The rhizosphere microbiome and plant health. Trends Plant Sci. 17, 478-486. doi: 10.1016/ j.tplants.2012.04.001

Besserer, A., Puech-Pàges, V., Kiefer, P., Gómez-Roldán, V., Jauneau, A., Roy, S., et al. (2006). Strigolactones stimulate arbuscular mycorrhizal fungi by activating mitochondria. PloS Biol. 4, 1239-1247. doi: 10.1371/ journal.pbio.0040226

Besserer, A., Bécard, G., Jauneau, A., Roux, C., and Séjalon-Delmas, N. (2008). GR24, a synthetic analog of strigolactones, stimulates the mitosis and growth of the arbuscular mycorrhizal fungus Gigaspora rosea by boosting its energy metabolism. Plant Physiol. 148, 402-413. doi: 10.1104/pp.108.121400

Besserer, A., Bécard, G., Roux, C., and Séjalon-Delmas, N. (2009). Role of mitochondria in the response of arbuscular mycorrhizal fungi to strigolactones. Plant Signal Behav. 4, 75-77. doi: 10.4161/psb.4.1.7419

Blumer, K. J., Reneke, J. E., and Thorner, J. (1988). The STE2 gene product is the ligand-binding component of the alpha-factor receptor of Saccharomyces cerevisiae. J. Biol. Chem. 263, 10836-10842.

Bowra, B. J., and Dilworth, M. J. (1981). Motility and chemotaxis towards sugars in Rhizobium leguminosarum. J. Gen. Microbiol. 126, 231-235. doi: 10.1099/ 00221287-126-1-231

Boyer, F. D., de Saint Germain, A., Pouvreau, J. B., Clavé, G., Pillot, J. P., Roux, A., et al. (2014). New strigolactone analogs as plant hormones with low activities in the rhizosphere. Mol. Plant 7, 675-690. doi: 10.1093/mp/sst163

Breakspear, A., Liu, C., Roy, S., Stacey, N., Rogers, C., Trick, M., et al. (2014). The root hair "infectome" of Medicago truncatula uncovers changes in cell cycle genes and reveals a requirement for auxin signaling in rhizobial infection. Plant Cell 26, 4680-4701. doi: 10.1105/tpc.114.133496

Burg, D., Guillaume, J., and Tailliez, R. (1982). Chemotaxis by Rhizobium meliloti. Arch. Microbiol. 133, 162-163. doi: 10.1007/BF00413532

Caetano-Anollés, G., Crist-Estes, D. K., and Bauer, W. D. (1988). Chemotaxis of Rhizobium meliloti to the plant flavone luteolin requires functional nodulation genes. J. Bacteriol. 170, 3164-3169. doi: 10.1128/JB.170.7.3164-3169.1988

Cangelosi, G. A., Ankenbauer, R. G., and Nester, E. W. (1990). Sugars induce the Agrobacterium virulence genes through a periplasmic binding protein and a transmembrane signal protein. Proc. Natl. Acad. Sci. U. S. A. 87 (17), 67086712. doi: $10.1073 /$ pnas.87.17.6708

Cardoso, C., Ruyter-Spira, C., and Bouwmeester, H. J. (2011). Strigolactones and root infestation by plant-parasitic Striga, Orobanche and Phelipanche spp. Plant Sci. 180 (3), 414-420. doi: 10.1016/j.plantsci.2010.11.007

Čepulytė, R., Danquah, W. B., Bruening, G., and Williamson, V. M. (2018). Potent Attractant for Root-Knot Nematodes in Exudates from Seedling Root Tips of Two Host Species. Sci. Rep. 8 (1), 10847. doi: 10.1038/s41598-018-29165-4

Chitwood, D. J. (2002). Phytochemical-based strategies for nematode control. Annu. Rev. Phytopathol. 40, 221-249. doi: 10.1146/annurev.phyto.40.032602.130045

Compant, S., Clement, C., and Sessitsch, A. (2010). Plant growth-promoting bacteria in the rhizo- and endosphere of plants: their role, colonization, mechanisms involved and prospects for utilization. Soil Biol. Biochem. 42, 669-678. doi: 10.1016/j.soilbio.2009.11.024

Cook, C. E., Whichard, L. P., Turner, B., Wall, M. E., and Egley, G. H. (1966). Germination of witchweed (Striga lutea Lour.): isolation and properties of a potent stimulant. Science 154, 1189-1190. doi: 10.1126/science.154.3753.1189

de Lillo, E., Pozzebon, A., Valenzano, D., and Duso, C. (2018). An Intimate Relationship Between Eriophyoid Mites and Their Host Plants - A Review. Front. Plant Sci. 9, 1786. doi: 10.3389/fpls.2018.01786

Dettmann, A., Heilig, Y., Valerius, O., Ludwig, S., and Seiler, S. (2014). Fungal communication requires the MAK-2 pathway elements STE-20 and RAS-2, the NRC-1 adapter STE-50 and the MAP kinase scaffold HAM-5. PloS Genet. 10, e1004762. doi: 10.1371/journal.pgen.1004762

Dharmatilake, A. J., and Bauer, W. D. (1992). Chemotaxis of Rhizobium meliloti towards Nodulation Gene-Inducing Compounds from Alfalfa Roots. Appl. Environ. Microbiol. 58 (4), 1153-1158. doi: 10.1128/AEM.58.4.1153-1158.1992

Di Pietro, A., García-MacEira, F.II, Méglecz, E., and Roncero, M.II (2001). A MAP kinase of the vascular wilt fungus Fusarium oxysporum is essential for root penetration and pathogenesis. Mol. Microbiol. 39 (5), 1140-1152. doi: 10.1111/ j.1365-2958.2001.02307.x
Dodueva, I. E., Lebedeva, M. A., Kuznetsova, K. A., Gancheva, M. S., Paponova, S. S., and Lutova, L. L. (2020). Plant tumors: a hundred years of study. Planta. 251 (4), 82. doi: $10.1007 / \mathrm{s} 00425-020-03375-5$

Dogra, G., Purschke, F. G., Wagner, V., Haslbeck, M., Kriehuber, T., Hughes, J. G., et al. (2012). Sinorhizobium meliloti CheA complexed with CheS exhibits enhanced binding to CheY1, resulting in accelerated CheY1 dephosphorylation. J. Bacteriol. 194, 1075-1087. doi: 10.1128/JB.06505-11

Dong, L., Li, X., Huang, L., Gao, Y., Zhong, L., Zheng, Y., et al. (2014). Lauric acid in crown daisy root exudate potently regulates root-knot nematode chemotaxis and disrupts Mi-flp-18 expression to block infection. J. Exp. Bot. 65 (1), 131141. doi: $10.1093 /$ jxb/ert356

Escobar, M. A., and Dandekar, A. M. (2003). Agrobacterium tumefaciens as an agent of disease. Trends Plant Sci. 8, 380-386. doi: 10.1016/S1360-1385(03) 00162-6

Favery, B., Quentin, M., Jaubert-Possamai, S., and Abad, P. (2016). Gall-forming root-knot nematodes hijack key plant cellular functions to induce multinucleate and hypertrophied feeding cells. J. Insect Physiol. 84, 60-69. doi: 10.1016/j.jinsphys.2015.07.013

Fleming, T. R., Maule, A. G., and Fleming, C. C. (2017). Chemosensory Responses of Plant Parasitic Nematodes to Selected Phytochemicals Reveal Long-Term Habituation Traits. J. Nematol. 49 (4), 462-471.

Goldwasser, Y., Yoneyama, K., Xie, X., and Yoneyama, K. (2008). Production of strigolactones by Arabidopsis thaliana responsible for Orobanche aegyptiaca seed germination. Plant Growth Regul. 55, 21-28. doi: 10.1007/s10725-0089253-z

Gómez-Roldán, V., Fermas, S., Brewer, P. B., Puech-Pagès, V., Dun, E. A., Pillot, J. P., et al. (2008). Strigolactone inhibition of shoot branching. Nature 455, 189-194. doi: 10.1038/nature07271

Götz, R., Limmer, N., Ober, K., and Schmitt, R. (1982). Motility and chemotaxis in two strains of Rhizobium with complex flagella. J. Gen. Microbiol. 128, 789798. doi: $10.1099 / 00221287-128-4-789$

Guinel, F. C., and Geil, R. D. (2002). A model for the development of the rhizobial and arbuscular mycorrhizal symbioses in legumes and its use to understand the roles of ethylene in the establishment of these two symbioses. Can. J. Bot. 80, 695-720. doi: 10.1139/b02-066

Gulash, M., Ames, P., Larosiliere, R. C., and Bergman, K. (1984). Rhizobia are attracted to localized sites on legume roots. Appl. Environ. Microbiol. 48 (1), 149-152. doi: 10.1128/AEM.48.1.149-152.1984

Gullan, P. J., Miller, D. R., and Cook, L. G. (2005). "Gall-inducing scale insects (Hemiptera: Sternorrhyncha: Coccoidea)," in Biology, ecology, and evolution of gallinducing arthropods, vol. 1 . Eds. A. Raman, C. W. Schaefer and T. M. Withers (Enfield, NH: Science Publishers), 159-230.

Gutjahr, C. (2014). Phytohormone signaling in arbuscular mycorhiza development. Curr. Opin. Plant Biol. 20, 26-34. doi: 10.1016/j.pbi. 2014.04.003

Hagen, D. C., McCaffrey, G., and Sprague, G. F. Jr. (1986). Evidence the yeast STE3 gene encodes a receptor for the peptide pheromone a factor: gene sequence and implications for the structure of the presumed receptor. Proc. Natl. Acad. Sci. U.S.A. 83, 1418-1422. doi: 10.1073/pnas.83.5.1418

Hassani, M. A., Duran, P., and Hacquard, S. (2018). Microbial interactions within the plant holobiont. Microbiome 6 (1), 58. doi: 10.1186/s40168-018-0445-0

Hirsch, A. M., and Kapulnik, Y. (1998). Signal transduction pathways in mycorrhizal associations: comparisons with the Rhizobium legume symbiosis. Fungal Genet. Biol. 23, 205-212. doi: 10.1006/fgbi.1998.1046

Horan, D. P., and Chilvers, G. A. (1990). Chemotropism - the key to ectomycorrhizal formation? New Phytol. 116, 297-301. doi: 10.1111/j.14698137.1990.tb04717.x

Horiuchi, J., Prithiviraj, B., Bais, H. P., Kimball, B. A., and Vivanco, J. M. (2005). Soil nematodes mediate positive interactions between legume plants and rhizobium bacteria. Planta. 222 (5), 848-857. doi: 10.1007/ s00425-005-0025-y

Hosoi, A., Katsuyama, T., Sasaki, Y., Kondo, T., Yajima, S., and Ito, S. (2017). Nitrate analogs as attractants for soybean cyst nematode. Biosci. Biotechnol. Biochem. 81 (8), 1542-1547. doi: 10.1080/09168451.2017.1332980

Huang, Z., Zhou, Q., Sun, P., Yang, J., and Guo, M. (2018). Two Agrobacterium tumefaciens $\mathrm{CheW}$ Proteins Are Incorporated into One Chemosensory Pathway with Different Efficiencies. Mol. Plant Microbe Interact. 31 (4), 460470. doi: 10.1094/MPMI-10-17-0255-R 
Jiang, Y., Wang, W., Xie, Q., Liu, N., Liu, L., Wang, D., et al. (2017). Plants transfer lipids to sustain colonization by mutualistic mycorrhizal and parasitic fungi. Science 356 (6343), 1172-1175. doi: 10.1126/science.aam9970

Khare, E., Mishra, J., and Arora, N. K. (2018). Multifaceted Interactions Between Endophytes and Plant: Developments and Prospects. Front. Microbiol. 9, 2732. doi: $10.3389 /$ fmicb.2018.02732

Kierul, K., Voigt, B., Albrecht, D., Chen, X. H., Carvalhais, L. C., and Borriss, R. (2015). Influence of root exudates on the extracellular proteome of the plant growth-promoting bacterium Bacillus amyloliquefaciens FZB42. Microbiology 161 (1), 131-147. doi: 10.1099/mic.0.083576-0

Kim, H., and Borkovich, K. A. (2004). A pheromone receptor gene, pre-1, is essential formating type-specific directional growth and fusion of trichogynes and female fertility in Neurospora crassa. Mol. Microbiol. 52, 1781-1798. doi: 10.1111/j.1365-2958.2004.04096.x

Kim, H., and Borkovich, K. A. (2006). Pheromones are essential for male fertility and sufficient to direct chemotropic polarized growth of trichogynes during mating in Neurospora crassa. Eukaryot. Cell 5, 544-554. doi: 10.1128/ EC.5.3.544-554.2006

Kim, H., and Farrand, S. K. (1998). Opine catabolic loci from Agrobacterium plasmids confer chemotaxis to their cognate substrates. Mol. Plant-Microbe Interact. 11, 131-143. doi: 10.1094/MPMI.1998.11.2.131

Kobae, Y., Kameoka, H., Sugimura, Y., Saito, K., Ohtomo, R., Fujiwara, T., et al. (2018). Strigolactone Biosynthesis Genes of Rice are Required for the Punctual Entry of Arbuscular Mycorrhizal Fungi into the Roots. Plant Cell Physiol. 59 (3), 544-553. doi: 10.1093/pcp/pcy001

Koske, R. E. (1982). Evidence for a volatile attractant from plant roots affecting germ tubes of a VA mycorrhizal fungus. Trans. Br. Mycol. Soc 79, 305-310. doi: 10.1016/S0007-1536(82)80118-6

Lacal, J., García-Fontana, C., Muñoz-Martínez, F., Ramos, J. L., and Krell, T. (2010). Sensing of environmental signals: classification of chemoreceptors according to the size of their ligand binding regions. Environ. Microbiol. 12 (11), 2873-2884. doi: 10.1111/j.1462-2920.2010.02325.x

Leeder, A. C., Palma-Guerrero, J., and Glass, N. L. (2011). The social network: decipheringfungal language. Nat. Rev. Microbiol. 9, 440-451. doi: 10.1038/ nrmicro2580

Li, B., Li, Y. Y., Wu, H. M., Zhang, F. F., Li, C. J., Li, X. X., et al. (2016). Root exudates drive interspecific facilitation by enhancing nodulation and N2 fixation. Proc. Natl. Acad. Sci. U. S. A. 113, 6496-6501. doi: 10.1073/pnas.1523580113

Lindquist, E. E., and Oldfield, G. N. (1996). "Evolution of eriophyoid mites in relation to their host plants," in Eriophyoid mites-their biology, natural enemies and control, World Crop Pests, vol. 6. Eds. E. E. Lindquist, M. W. Sabelis and J. Bruin (Amsterdam: Elsevier Science Publishing), 277-300.

Loake, G. J., Ashby, A. M., and Shaw, C. H. (1988). Attraction of Agrobacterium tumefaciens $\mathrm{C} 58 \mathrm{C} 1$ towards sugars involves a highly sensitive chemotaxis system. Microbiology 134, 1427-1432. doi: 10.1099/00221287-134-6-1427

Lombardi, N., Vitale, S., Turrà, D., Reverberi, M., Fanelli, C., Vinale, F., et al. (2018). Root Exudates of Stressed Plants Stimulate and Attract Trichoderma Soil Fungi. Mol. Plant Microbe Interact. 31 (10), 982-994. doi: 10.1094/MPMI12-17-0310-R

López-Ráez, J. A., Fernández, I., García, J. M., Berrio, E., Bonfante, P., Walter, M. H., et al. (2015). Differential spatio-temporal expression of carotenoid cleavage dioxygenases regulates apocarotenoid fluxes during AM symbiosis. Plant Sci. 230, 59-69. doi: 10.1016/j.plantsci.2014.10.010

Luginbuehl, L. H., Menard, G. N., Kurup, S., Van Erp, H., Radhakrishnan, G. V., Breakspear, A., et al. (2017). Fatty acids in arbuscular mycorrhizal fungi are synthesized by the host plant. Science 356 (6343), 1175-1178. doi: 10.1126/ science.aan0081

Mabrouk, Y., Zourgui, L., Sifi, B., Delavault, P., Simier, P., and Belhadj, O. (2007a). Some compatible Rhizobium leguminosarum strains in peas decrease infections when parasitised by Orobanche crenata. Weed Res. 47, 44-53. doi: 10.1111/ j.1365-3180.2007.00548.x

Mabrouk, Y., Zourgui, L., Sifi, B., and Belhadj, O. (2007b). The potential of Rhizobium strains for biological control of Orobanche crenata. Biologia 62, 139-143. doi: 10.2478/s11756-007-0021-8

Mabrouk, Y., Simier, P., Arfaoui, A., Sifi, B., Delavault, P., Zourgui, L., et al. (2007c). Induction of phenolic compounds in pea (Pisum sativum L.) inoculated by Rhizobium leguminosarum and infected with Orobanche crenata. J. Phytopathol. 155, 728-734. doi: 10.1111/j.1439-0434.2007.01307.x
Malek, W. (1989). Chemotaxis in Rhizobium meliloti strain L5.30. Microbiology 152, 611-612. doi: 10.1007/BF00425496

Manohar, M., Tenjo-Castano, F., Chen, S., Zhang, Y. K., Kumari, A., Williamson, V. M., et al. (2020). Plant metabolism of nematode pheromones mediates plant-nematode interactions. Nat. Commun. 11 (1), 208. doi: 10.1038/s41467019-14104-2

Manosalva, P., Manohar, M., von Reuss, S. H., Chen, S., Koch, A., Kaplan, F., et al. (2015). Conserved nematode signalling molecules elicit plant defenses and pathogen resistance. Nat. Commun. 6, 7795. doi: 10.1038/ncomms8795

Manson, D. C. M., and Oldfield, G. N. (1996). "Life forms, deuterogyny, diapause and seasonal development," in Eriophyoid mites-their biology, natural enemies and control, vol. 6. Eds. E. E. Lindquist, M. W. Sabelis and J. Bruin (Amsterdam: Elsevier Science Publishing), 173-183.

Martin, F. M., Uroz, S., and Barker, D. G. (2017). Ancestral alliances: plant mutualistic symbioses with fungi and bacteria. Science 356, eaad4501. doi: $10.1126 /$ science.aad 4501

Massee, G. (1905). On the origin of parasitism in fungi. Philos. Trans. R. Soc 197, 7-24. doi: 10.1098/rstb.1905.0003

Meier, V. M., and Scharf, B. E. (2009). Cellular localization of predicted transmembrane and soluble chemoreceptors in Sinorhizobium meliloti. J. Bacteriol. 191, 5724-5733. doi: 10.1128/JB.01286-08

Meier, V. M., Muschler, P., and Scharf, B. E. (2007). Functional analysis of nine putative chemoreceptor proteins in Sinorhizobium meliloti. J. Bacteriol. 189, 1816-1826. doi: 10.1128/JB.00883-06

Miller, L. D., Yost, C. K., Hynes, M. F., and Alexandre, G. (2007). The major chemotaxis gene cluster of Rhizobium leguminosarum bv. viciae is essential for competitive nodulation. Molec. Microbiol. 63, 348-362. doi: 10.1111/j.13652958.2006.05515.x

Mori, I. (1999). Genetics of chemotaxis and thermotaxis in the nematode Caenorhabditis elegans. Annu. Rev. Genet. 33, 399-422. doi: 10.1146/ annurev.genet.33.1.399

Nagahashi, G., and Douds, D. D. (2000). Partial separation of root exudate components and their effects upon the growth of germinated spores of AM fungi. Mycol. Res. 104, 1453-1464. doi: 10.1017/S0953756200002860

Nagahashi, G., and Douds, D. D. (2007). Separated components of root exudate and cytosol stimulate different morphologically identifiable types of branching responses by arbuscular mycorrhizal fungi. Mycol. Res. 111, 487-492. doi: 10.1016/j.mycres.2007.02.007

Nault, L. R., and Styer, W. E. (1969). The dispersal of Aceria tulipae and three other grass-infesting eriophyid mites in Ohio. Ann. Entomol. Soc Am. 62, 1446-1455. doi: 10.1093/aesa/62.6.1446

Ohri, P., and Pannu, S. K. (2010). Effect of phenolic compounds on nematodes - A review. J. Nat. Appl. Sci. 2, 344-350. doi: 10.31018/jans.v2i2.144

Oota, M., Tsai, A. Y., Aoki, D., Matsushita, Y., Toyoda, S., Fukushima, K., et al. (2019). Identification of naturally-occurring polyamines as nematode Meloidogyne incognita attractants. Mol. Plant. 13, 658-665. doi: 10.1016/ j.molp.2019.12.010

Papademetriou, M. K., and Bone, L. W. (1983). Chemotaxis of larval soybean cyst nematode, Heterodera glycines Race 3, to root leachates and ions. J. Chem. Ecol. 9 (3), 387-396. doi: 10.1007/BF00988457

Parniske, M. (2008). Arbuscular mycorrhiza: the mother of plant root endosymbioses. Nat. Rev. Microbiol. 6, 763-775. doi: 10.1038/nrmicro1987

Platzer, J., Sterr, W., Hausmann, M., and Schmitt, R. (1997). Three genes of a motility operon and their role in flagellar rotary speed variation in Rhizobium meliloti. J. Bacteriol. 179, 6391-6399. doi: 10.1128/JB.179.20.6391-6399.1997

Pline, M., and Dusenbery, D. B. (1987). Responses of plant-parasitic nematode Meloidogyne incognita to carbon dioxide determined by video cameracomputer tracking. J. Chem. Ecol. 13 (4), 873-888. doi: 10.1007/BF01020167

Poole, P., Ramachandran, V., and Terpolilli, J. (2018). Rhizobia: from saprophytes to endosymbionts. Nat. Rev. Microbiol. 16 (5), 291-303. doi: 10.1038/ nrmicro.2017.171

Quist, C. W., Smant, G., and Helder, J. (2015). Evolution of plant parasitism in the phylum Nematoda. Annu. Rev. Phytopathol. 53, 289-310. doi: 10.1146/ annurev-phyto-080614-120057

Raman, A., Schaefer, C. W., and Withers, T. M. (2005). "Galls and gall-inducing arthropods: an overview of their biology, ecology and evolution," in Biology, ecology, and evolution of gall-inducing arthropods, vol. 1. Eds. A. Raman, C. W. Schaefer and T. M. Withers (Enfield, NH: Science Publishers), 1-33. 
Rasmann, S., Ali, J. G., Helder, J., and van der Putten, W. H. (2012). Ecology and evolution of soil nematode chemotaxis. J. Chem. Ecol. 38, 615-628. doi: 10.1007/s10886-012-0118-6

Read, N. D., Lichius, A., Shoji, J. Y., and Goryachev, A. B. (2009). Self-signalling and self-fusion in filamentous fungi. Curr. Opin. Microbiol. 12 (6), 608-615. doi: 10.1016/j.mib.2009.09.008

Read, N. D., Goryachev, A. B., and Lichius, A. (2012). The mechanistic basis of self-fusion between conidial anastomosis tubes during fungal colony initiation. Fungal Biol. Rev. 26, 1-11. doi: 10.1016/j.fbr.2012.02.003

Rengarajan, S., and Hallem, E. A. (2016). Olfactory circuits and behaviors of nematodes. Curr. Opin. Neurobiol. 41, 136-148. doi: 10.1016/j.conb.2016. 09.002

Reynolds, A. M., Dutta, T. K., Curtis, R. H., Powers, S. J., Gaur, H. S., and Kerry, B. R. (2011). Chemotaxis can take plant-parasitic nematodes to the source of a chemo-attractant via the shortest possible routes. J. R. Soc Interface. 8 (57), 568-577. doi: 10.1098/rsif.2010.0417

Roca, M. G., Arlt, J., Jeffree, C. E., and Read, N. D. (2005). Cell biology of conidial anastomosis tubes in Neurospora crassa. Eukaryot. Cell 4, 911-919. doi: 10.1128/EC.4.5.911-919.2005

Sabelis, M. W., and Bruin, J. (1996). "Evolutionary ecology: life history patterns, food plant choice and dispersal," in Eriophyoid mites-their biology, natural enemies and control, vol. 6. Eds. E. E. Lindquist, M. W. Sabelis and J. Bruin (Amsterdam: Elsevier Science Publishing), 329-366.

Sampedro, I., Parales, R. E., Krell, T., and Hill, J. E. (2015). Pseudomonas chemotaxis. FEMS Microbiol. Rev. 39 (1), 17-46. doi: 10.1111/1574-6976.12081

Sbrana, C., and Giovannetti, M. (2005). Chemotropism in the arbuscular mycorrhizal fungus Glomus mosseae. Mycorrhiza. 15, 539-545. doi: 10.1007/ s00572-005-0362-5

Scharf, B. E., Hynes, M. F., and Alexandre, G. M. (2016). Chemotaxis signaling systems in model beneficial plant-bacteria associations. Plant Mol. Biol. 90 (6), 549-559. doi: 10.1007/s11103-016-0432-4

Schrick, K., Garvik, B., and Hartwell, L. H. (1997). Mating in Saccharomyces cerevisiae: the role of the pheromone signal transduction pathway in the chemotropic response to pheromone. Genetics 147, 19-32.

Sengupta, P., Chou, J. H., and Bargmann, C.II (1996). odr-10 encodes a seven transmembrane domain olfactory receptor required for responses to the odorant diacetyl. Cell 84 (6), 899-909. doi: 10.1016/S0092-8674(00)81068-5

Shivakumara, T. N., Dutta, T. K., Chaudhary, S., von Reuss, S. H., Williamson, V. M., and Rao, U. (2019). Homologs of Caenorhabditis elegans Chemosensory Genes Have Roles in Behavior and Chemotaxis in the Root-Knot Nematode Meloidogyne incognita. Mol. Plant Microbe Interact. 32 (7), 876-887. doi: 10.1094/MPMI-0818-0226-R

Siddique, S., and Grundler, F. M. (2018). Parasitic nematodes manipulate plant development to establish feeding sites. Curr. Opin. Microbiol. 46, 102-108. doi: 10.1016/j.mib.2018.09.004

Sourjik, V., and Schmitt, R. (1996). Different roles of CheY1 and CheY2 in the chemotaxis of Rhizobium meliloti. Mol. Microbiol. 22, 427-436. doi: 10.1046/ j.1365-2958.1996.1291489.x

Sourjik, V., and Schmitt, R. (1998). Phosphotransfer between CheA, CheY1, and CheY2 in the chemotaxis signal transduction chain of Rhizobium meliloti. Biochemistry 37, 2327-2335. doi: 10.1021/bi972330a

Straney, D., Ruan, Y., and He, J. (1994). In vitro transcription and binding analysis of promoter regulation by a host-specific signal in a phytopathogenic fungus. Antonie Van Leeuwenhoek. 65, 183-189. doi: 10.1007/BF00871945

Straney, D., Khan, R., Tan, R., and Bagga, S. (2002). Host recognition by pathogenic fungi through plant flavonoids. Adv. Exp. Med. Biol. 505, 9-22. doi: 10.1007/978-1-4757-5235-9_2

Strullu-Derrien, C., Selosse, M. A., Kenrick, P., and Martin, F. M. (2018). The origin and evolution of mycorrhizal symbioses: from palaeomycology to phylogenomics. New Phytol. 220, 1012-1030. doi: 10.1111/nph.15076

Taniguchi, G., Uozumi, T., Kiriyama, K., Kamizaki, T., and Hirotsu, T. (2014). Screening of odor-receptor pairs in Caenorhabditis elegans reveals different receptors for high and low odor concentrations. Sci. Signal 7, ra39. doi: 10.1126/scisignal.2005136

Tisserant, E., Kohler, A., Dozolme-Seddas, P., Balestrini, R., Benabdellah, K., Colard, A., et al. (2012). The transcriptome of the arbuscular mycorrhizal fungus Glomus intraradices (DAOM 197198) reveals functional trade-offs in an obligate symbiont. New Phytol. 193, 755-769. doi: 10.1111/j.14698137.2011.03948.x

Tooker, J. F., and Helms, A. M. (2014). Phytohormone dynamics associated with gall insects, and their potential role in the evolution of the gall-inducing habit. J. Chem. Ecol. 40 (7), 742-753. doi: 10.1007/s10886-014-0457-6

Tsai, A. Y., Higaki, T., Nguyen, C. N., Perfus-Barbeoch, L., Favery, B., and Sawa, S. (2019). Regulation of Root-Knot Nematode Behavior by Seed-Coat MucilageDerived Attractants. Mol. Plant 12 (1), 99-112. doi: $10.1016 /$ j.molp.2018.11.008

Turrà, D., and Di Pietro, A. (2015). Chemotropic sensing in fungus-plant interactions. Curr. Opin. Plant Biol. 26, 135-140. doi: 10.1016/j.pbi.2015.07.004

Turrà, D., El Ghalid, M., Rossi, F., and Di Pietro, A. (2015). Fungal pathogen uses sex pheromone receptor for chemotropic sensing of host plant signals. Nature 527, 521-524. doi: 10.1038/nature15516

Turrà, D., Nordzieke, D., Vitale, S., El Ghalid, M., and Di Pietro, A. (2016). Hyphal chemotropism in fungal pathogenicity. Semin. Cell Dev. Biol. 57, 69-75. doi: 10.1016/j.semcdb.2016.04.020

van der Does, H. C., Duyvesteijn, R. G., Goltstein, P. M., van Schie, C. C., Manders, E. M., Cornelissen, B. J., et al. (2008). Expression of effector gene SIX1 of Fusarium oxysporum requires living plant cells. Fungal Genet. Biol. 45, $1257-$ 1264. doi: 10.1016/j.fgb.2008.06.002

van Zeijl, A., Liu, W., Xiao, T. T., Kohlen, W., Yang, W. C., Bisseling, T., et al. (2015). The strigolactone biosynthesis gene DWARF27 is co-opted in rhizobium symbiosis. BMC Plant Biol. 15, 260. doi: 10.1186/s12870-0150651-X

Vierheilig, H., and Piché, Y. (2002). "Signalling in arbuscular mycorrhiza: facts and hypotheses," in Flavonoids in cell function. Eds. B. Buslig and J. A. Manthey (New York: Kluwer Academic), 23-39.

Wadhams, G. H., and Armitage, J. P. (2004). Making sense of it all: bacterial chemotaxis. Nat. Rev. Mol. Cell Biol. 5, 1024-1037. doi: 10.1038/nrm1524

Walker, T. S., Bais, H. P., Grotewold, E., and Vivanco, J. M. (2003). Root exudation and rhizosphere biology. Plant Physiol. 132, 44-51. doi: 10.1104/pp.102.019661

Wang, C., Lower, S., and Williamson, V. M. (2009). Application of pluronic gel to the study of root-knot nematode behaviour. Nematology 11, 453-464. doi: $10.1163 / 156854109 \mathrm{X} 447024$

Wang, C., Lower, S., Thomas, V. P., and Williamson, V. M. (2010). Root-knot nematodes exhibit strain-specific clumping behavior that is inherited as a simple genetic trait. PloS One 5 (12), e15148. doi: 10.1371/journal.pone. 0015148

Wang, C., Masler, E. P., and Rogers, S. T. (2018). Responses of Heterodera glycines and Meloidogyne incognita Infective Juveniles to Root Tissues, Root Exudates, and Root Extracts from Three Plant Species. Plant Dis. 102 (9), 1733-1740. doi: 10.1094/PDIS-09-17-1445-RE

Webb, B. A., Hildreth, S., Helm, R. F., and Scharf, B. E. (2014). Sinorhizobium meliloti chemoreceptor McpU mediates chemotaxis toward host plant exudates through direct proline sensing. Appl. Environ. Microbiol. 80 (11), 3404-3415. doi: 10.1128/AEM.00115-14

Webb, B. A., Compton, K. K., Del Campo, J. S. M., Taylor, D., Sobrado, P., and Scharf, B. E. (2017a). Sinorhizobium meliloti Chemotaxis to Multiple Amino Acids Is Mediated by the Chemoreceptor McpU. Mol. Plant Microbe Interact. 30 (10), 770-777. doi: 10.1094/MPMI-04-17-0096-R

Webb, B. A., Compton, K. K., Castañeda Saldaña, R., Arapov, T. D., Keith Ray, W., and Helm, R. F. (2017b). Sinorhizobium meliloti chemotaxis to quaternary ammonium compounds is mediated by the chemoreceptor McpX. Mol. Microbiol. 103 (2), 333-346. doi: 10.1111/mmi.13561

Wuichet, K., and Zhulin, I. B. (2010). Origins and diversification of a complex signal transduction system in prokaryotes. Sci. Signal 3, ra50. doi: 10.1126/ scisignal.2000724

Xu, Z., Zhao, Y. Q., Yang, D. J., Sun, H. J., Zhang, C. L., and Xie, Y. P. (2015). Attractant and repellent effects of sweet potato root exudates on the potato rot nematode, Ditylenchus destructor. Nematology 17 (1), 117-124. doi: 10.1163/ 15685411-00002856

Yang, W., and Briegel, A. (2020). Diversity of Bacterial Chemosensory Arrays. Trends Microbiol. 28 (1), 68-80. doi: 10.1016/j.tim.2019.08.002

Yang, G., Zhou, B., Zhang, X., Zhang, Z., Wu, Y., Zhang, Y., et al. (2016). Effects of Tomato Root Exudates on Meloidogyne incognita. PloS One 11 (4), e0154675. doi: 10.1371/journal.pone.0154675 
Yoneyama, K., Xie, X., Sekimoto, H., Takeuchi, Y., Ogasawara, S., Akiyama, K., et al. (2008). Strigolactones, host recognition signals for root parasitic plants and arbuscular mycorrhizal fungi, from Fabaceae plants. New Phytol. 179, 484494. doi: 10.1111/j.1469-8137.2008.02462.x

Yost, C. K., Rochepeau, P., and Hynes, M. F. (1998). Rhizobium leguminosarum contains a group of genes that appear to code for methylaccepting chemotaxis proteins. Microbiology 144, 1945-1956. doi: 10.1099/ 00221287-144-7-1945

Zhao, X., Schmitt, M., and Hawes, M. C. (2000). Species-dependent effects of border cell and root tip exudates on nematode behavior. Phytopathology 90 (11), 1239-1245. doi: 10.1094/PHYTO.2000.90.11.1239

Zhao, L. L., Wei, W., Kang, L., and Sun, J. H. (2007). Chemotaxis of the pinewood nematode, Bursaphelenchus xylophilus, to volatiles associated with host pine,
Pinus massoniana, and its vector Monochamus alternatus. J. Chem. Ecol. 33 (6), 1207-1216. doi: 10.1007/s10886-007-9289-y

Conflict of Interest: The authors declare that the research was conducted in the absence of any commercial or financial relationships that could be construed as a potential conflict of interest.

Copyright (C) 2020 Tsai, Oota and Sawa. This is an open-access article distributed under the terms of the Creative Commons Attribution License (CC BY). The use, distribution or reproduction in other forums is permitted, provided the original author(s) and the copyright owner(s) are credited and that the original publication in this journal is cited, in accordance with accepted academic practice. No use, distribution or reproduction is permitted which does not comply with these terms. 